\title{
Imitating the Devil: Cyprian on Jealousy and Envy
}

\author{
Edwina Murphy \\ Morling College (Australian College of Theology and University of Divinity) \\ edwinam@morling.edu.au
}

\begin{abstract}
If imitating Christ in his humility leads to peace and unity, imitating the devil in his jealousy leads to conflict and self-destruction. So warns Cyprian of Carthage in De zelo et livore, where he identifies the devil as the originator of envy, precipitating humanity's downfall as well as his own. Cyprian further illustrates these fatal effects by pairing exemplars of jealousy with their innocent victims. Cyprian's use of these models demonstrates the importance of this reading strategy for his exegesis and the value he ascribes to imitation in Christian formation. Furthermore, whilst Cyprian's emphasis on unity is well known, this study highlights that it is not achieved simply by avoiding schism. Rather, structural concerns are just one expression of Cyprian's conviction that conflict and division are vices rooted in the flesh. Those who claim to be Christians must, like Christ, live according to the Spirit in love and peace.
\end{abstract}

\section{Keywords}

biblical interpretation - patristic exegesis - reception of Scripture

Cyprian, like others in the early church, is well known for his emphasis on the imitation of Christ. ${ }^{1}$ But what does it look like to imitate the devil? Whereas Christ is a model of humility, and following him will lead to peace and unity, the devil was the source of the jealousy and envy that caused his own downfall and that of humanity. Those who follow him stir up conflict and dissension, resulting in attempted and, on occasion, actual murder. Cain, Esau, Joseph's

1 See Simone Deléani, Christum sequi:Étude d'un thème dans l'oeuvre de saint Cyprien, Paris, 1979. 
brothers, Saul, and the Jews all demonstrate the serious nature of jealousy and provide warnings against succumbing to it.

Such use of models is one of the key ways in which Cyprian appropriates the Scriptures, ${ }^{2}$ which he regards as central to spiritual formation. ${ }^{3}$ These exemplars both encourage righteousness and warn against sin. Cyprian's most frequently used exemplar is Christ, followed by Paul, but a range of Old and New Testament figures are pressed into service. ${ }^{4}$ This reading strategy is prominent in both De opere et eleemosynis and Ad Fortunatum, as well as here. ${ }^{5}$ Many of the examples in De zelo et livore, both positive and negative, are also used in De bono patientiae, showing the opposition in Cyprian's mind between Christ-like patience, the undergirder of unity, and devilish jealousy and envy, the result of impatience and the destroyer of harmony. But in De zelo et livore, Cyprian expressly states his intention to warn his flock so they might be on guard against the adversary who seeks to devour them. ${ }^{6}$

The originator of envy is the devil. In Cyprian's account, the adversary did not envy God, but rather humans whom God made in his own image. This reasoning is an inference drawn from Wisdom 2:23, "For God created man to be

2 For reading strategies which relate to the early church's appropriation of the entire Scripture, see Frances M. Young, Biblical Exegesis and the Formation of Christian Culture, Cambridge, 1997, pp. 212-213. For some of the strategies Cyprian himself uses, see Edwina Murphy, "Divine Ordinances and Life-Giving Remedies: Galatians in the Writings of Cyprian of Carthage," JTI, 8 (2014), pp. 81-101. These almost all fall within the overarching strategy of paraenesis including, as Stanley Stowers defines it, "not only precepts but also such things as advice, supporting argumentation, various modes of encouragement and dissuasion, the use of examples, models of conduct, and so on." Stanley K. Stowers, Letter Writing in Greco-Roman Antiquity, Philadelphia, PA, 1986, p. 23.

3 G.W. Clarke, The Letters of St. Cyprian of Carthage, 4 vols., New York, 1984-1989, vol. 1, p. 356 n. 2. All English translations of Cyprian's letters are from this edition.

4 For a list of "Biblical Figures" employed by Cyprian, see Michael Andrew Fahey, Cyprian and the Bible: A Study in Third-Century Exegesis, Tübingen, 1971, pp. 555-611.

5 See, for example, Cyprian's use of faithful parents in these works discussed in Edwina Murphy, "Cyprian, Parenthood, and the Hebrew Bible: Modelling Munificence and Martyrdom," StPatr (forthcoming, 2018). As Geoffrey Dunn notes, however, Cyprian does not present Mary as a model of either virginity or motherhood. Geoffrey D. Dunn, "References to Mary in the Writings of Cyprian of Carthage," StPatr, 42 (2006), 376-378.

6 Zel. liv. 1-3 (CCSL 3A:75-76). Translations of the treatises are modified from ANF. 
immortal, and he made him in the image of his own likeness,"7 which is followed by the verses that Cyprian quotes from Wisdom 2:24-25 on death entering the world through the envy of the devil, suggesting that the creation of people in God's image was the source of that envy:

Because of this, at the very beginning of the world, the devil was the first both to perish and to destroy. He who was upheld in angelic majesty, he who was accepted and loved by God, when he saw humans made in the image of God, burst out into jealousy with malevolent envy - not hurling down another by the instinct of his jealousy before he himself was first hurled down by jealousy, captive before taking captive, ruined before ruining others. While, spurred on by envy, he takes away from humanity the grace of immortality given, he himself has lost what he had previously been. How great an evil it is, beloved brethren, by which an angel fell, by which that high and glorious transcendence could be defrauded and overthrown, by which he who deceived was himself deceived! Since then envy rages on the earth, as the one who is about to perish by envy follows the author of their ruin, imitating the devil in his jealousy; as it is written, "But through the envy of the devil death entered into the world. ${ }^{8}$ Therefore those who are on his side imitate him."

7 Wis 2:23. Cf. Vulgate: "quoniam Deus creavit hominem inexterminabilem et ad imaginem suae similitudinis fecit illum." It is true, as Poirier says, that the original source of the idea is Gen 1:26-27, but Wisdom is the direct source of Cyprian's argument. Michel Poirier, Cyprien de Carthage: La jalousie et l'envie, Paris, 2008, p. 72.

8 Wis 2:24.

9 "Hinc diabolus inter initia statim mundi et perit primus et perdidit. Ille angelica maiestate subnixus, ille Deo acceptus et carus postquam hominem ad imaginem Deifactum conspexit, in zelum maliuolo liuore prorupit, non prius alterum deiciens instinctu zeli quam ipse zelo ante deiectus, catiuus ante quam capiens, perditus ante quam perdens, dum stimulante liuore homini gratiam datae immortalitatis eripir, ipse quoque id quod prius fuerat amisit. Quale malum est, fratres dilectissimi, quo angelus cecidit, quo circumueniri et subuerti alta illa et praeclara sublimitas potuit, quo deceptus est ipse qui decepit. Exinde inuidia grassatur in terris, dum liuore periturus magistro perditionis obsequitur, dum diabolum qui zelat imitatur, sicut scriptum est: 'Inuidia autem diaboli mors introiuit in orbum terrarum. Imitantur ergo illum qui sunt ex parte eius." Zel. liv. 4 (CCSL 3A:76-77). With Poirier, I take the final sentence as a citation of Wis 2:25 in its Latin form, which differs from the Greek, probably the reason it is not regarded as a citation in CCSL (3A:77). Poirier, Jalousie et l'envie, pp. 72-74. Cyprian's text is almost identical to the Vulgate, which reads: "imitantur autem illum qui sunt ex parte illius." For the early exegetical traditions seeking to explain the devil's envy, see James Kugel, Traditions of the Bible: A Guide to the Bible as It Was at the Beginning of the Common Era, Cambridge, MA, 1998, pp. 121-124. 
To be jealous is therefore to imitate the devil. Such imitation leads to one's own ruin, just as the devil first destroyed himself before causing the destruction of others. Cyprian will examine the psychological impact jealousy and envy have on the person who follows this path ${ }^{10}$ - the internal strife they cause - but he begins with the interpersonal dimensions of conflict, and that will be my focus here.

The assertion that the imitation of the devil results in perdition is also found in De bono patientiae, but the cause identified is somewhat different. In chapter 19, beginning with the devil, Cyprian lists those who were prompted by impatience:

For as patience is the benefit of Christ, so, on the other hand, impatience is the evil of the devil; and as one in whom Christ dwells and abides is found patient, so he appears always impatient whose mind is possessed by the wickedness of the devil. Briefly let us look at the very beginnings. The devil suffered with impatience that humans were made in the image of God. Hence he was the first to perish and to ruin others. ${ }^{11}$

Just as imitating the devil in his jealousy leads to destruction, so does imitating him in his impatience. There is a specific contrast here between the patience which results from the indwelling of Christ and the impatience which comes from being controlled by the devil. Cyprian does not see such possession, either by Christ or the devil, as overriding a person's free will. ${ }^{12}$ Rather, it is linked with the choice to imitate one or the other. ${ }^{13}$ The opposition of Christ and the devil is typical of Cyprian's "two ways." The Christian life is a spiritual battle,

Zel. liv. 7-9 (CCSL 3A:78-80). There is then a return to biblical reflection, with numerous NT references in chapters 10-13. So, as Poirier says, "les deux Testaments encadrent une réflexion d'ordre psychologique qui se situe à un niveau moins spécifiquement religieux." Poirier, Jalousie et l'envie, p. 14.

"Nam ut patientia bonum Christi est, ita contra impatientia diaboli malum est, et sicut in quo habitat et manet Christus patiens inuenitur, ita impatiens semper existit cuius mentem diaboli nequitia possedit. Exordia denique ipsa uideamus. Diabolus hominem ad imaginem Dei factum impatienter tulit: inde et perit primus et perdidit." Pat. 19 (CCSL 3A:129). Tertullian also ascribes impatience to the devil, but the reason differs - God subjected his creation to humanity. Pat. 5.5 (CCSL 1:303). Each person has the freedom to choose whether or not to follow Christ, but the church, like Peter, will never depart from him. Quoting John 6:68, 69-70. Ep. 59.7.2-3 (CCSL 3 C:348). In his letter to Magnus, for example, Cyprian states that the devil is completely defeated in baptism. The subsequent return of evil spirits is the result of falling into sin, not the other way around. Ep. 69.15.1-16.1 (CCSL 3 C:493-495). 
but the ultimate victory of Christ is never in doubt. The Christian must conquer the flesh and defend against the darts of the devil - such faithfulness will be rewarded..$^{14}$

As I examine Cyprian's demonstration of the dangers of imitating the devil in his envy through his list of exemplars in De zelo et livore, I will also consider the other appearances of those characters in his work, particularly those in $D e$ bono patientiae where (almost) the same cast appears, imitating the devil in his impatience..$^{15}$ In the conclusion, I will consider the link between these two works and whether we can learn anything about the order in which they were written from Cyprian's use of these texts.

Cyprian moves from the devil, "at the very beginnings of the world," to those who imitate him, along with the devastating results. These he considers in chronological order: ${ }^{16}$

And so began the primal hatreds of the new brotherhood, the abominable parricides, as the unrighteous Cain is jealous of the righteous Abel, as the evil persecutes the good with hatred and envy. So strong was the rage of rivalry to complete the wrongdoing, that neither the love of his brother, nor the enormity of the crime, nor the fear of God, nor the penalty of the sin, was considered. He was unrighteously oppressed who had been the first to show righteousness; he endured hatred who had not known how to hate; he was impiously slain, who, dying, did not resist. ${ }^{17}$

14 Zel. liv. 16 (CCSL 3A:84-85).

15 Abraham and Isaac also appear in Pat. 10 (CCSL 3A:123) for their patience, but are not included in De zelo et livore as they are not the victims of jealousy, but rather each is patient in the trial of the sacrifice commanded.

This form of historical awareness is noted by Nienke Vos, "A Universe of Meaning: Cyprian's Use of Scripture in Letter 58," in Cyprian of Carthage: Studies in His Life, Language and Thought, ed. Henk Bakker, Paul van Geest, and Hans van Loon, Leuven, 2010, p. 91.

"Hinc denique nouae fraternitatis prima odia, hinc parricidia nefanda coeperunt, dum Abel iustum Cain zelat iniustus, dum bonum malus inuidia et liuore persequitur. Tantum ualuit ad consummationem facinoris aemulationis furor, ut nec caritas fratris nec sceleris immanitas nec timor Dei nec poena delicti cogitaretur. Iniuste oppressus est qui iustitiam primus ostenderat, odia perpessus est qui odisse non nouerat, occisus est impie qui moriens non repugnabat." Zel. liv. 5 (ccsL 3A:77). 
After this introduction as one driven by jealousy to commit a terrible crime, Cain becomes a shorthand term in De zelo et livore for the dangers of envy. Since his hatred of his brother led to murder, anyone who hates their brother is a murderer, as 1 John says. ${ }^{18}$ Cain cannot return to paradise, and neither can those who follow him in his dissension, since the Lord only admits those who are of one heart and mind. ${ }^{19}$ Likewise, in chapter 19 of De bono patientiae, we find Cain at the head of a list, after the devil and Adam, ${ }^{20}$ in which impatience is the cause of strife: "And in order that Cain should put his brother to death, he was impatient of his sacrifice and gift." ${ }^{21}$

If Cain is one of the envious and impatient who follow the author of their ruin, Abel introduces a list of righteous people in De bono patientiae "who in their preceding likeness bore the figure of Christ." ${ }^{22}$ These exemplars were all determined to maintain patience, whatever the provocation:

So Abel, who first initiated and dedicated the origin of martyrdom and the passion of the righteous, does not resist or struggle against his parricidal brother, but with humility and meekness is patiently slain. ${ }^{23}$

As Fahey notes, these passages in De zelo et livore and De bono patientiae share "a curious non-scriptural detail about Abel, that he 'willingly' accepted his martyrdom without struggle." 24 This would appear to be related to him being a precursor of Christ - since Christ willingly suffered, this same attitude is read back into Abel.

18 1 John 3:15. Zel. liv. 11 (CCSL 3A:80-81).

19 Zel. liv. 18 (CCSL 3 A:85).

20 "Adam, contrary to the heavenly precepts regarding the deadly food, by impatience fell into death; nor did he preserve the divine grace he received under the guardianship of patience." "Adam contra caeleste praeceptum cibi letalis impatiens in mortem cecidit nec acceptam diuinitus gratiam patientia custode seruauit." Pat. 19 (CCSL 3A:129).

21 "et ut fratrem Cain perimerit sacrificii eius et muneris impatiens fuit." Pat. 19 (CCSL 3A:129).

22 "quifiguram Christi imagine praeeunte portabant." Pat.10 (CCSL 3A:123). Job is not included in this list, but is instead referred to later (Pat. 18 [CCSL 3A:128-129]), perhaps because of the differing circumstances of his patience. For Job as an exemplum in Tertullian and Cyprian, see Jean Daniélou, A History of Early Christian Doctrine Before the Council of Nicaea. Vol. 3: The Origins of Latin Christianity, trans. David Smith and John Austin Baker, London, 1977, pp. 324-326.

23 "Sic Abel originem martyrii et passionem iusti initians primus et dedicans, aduersus fratrem parricidam non resistit nec reluctatur, sed humilis et mitis patienter occiditur." Pat. 10 (CCSL 3A:123).

Fahey, Cyprian, p. 560. 
Cain and Abel also appear in De dominica oratione, as part of a lengthy discussion on the importance of peace and concord:

For even in the sacrifices which Abel and Cain first offered, God looked not at their gifts, but at their hearts, so that he was acceptable in his gift who was acceptable in his heart. Abel, peaceable and righteous, sacrificing in innocence to God, also taught others when they bring their gift to the altar, to come in this way with the fear of God, with a simple heart, with the law of righteousness, with the peace of concord. Deservedly, he who was like this regarding God's sacrifice, later himself became a sacrifice to God; so that the one who first set forth martyrdom, and initiated the Lord's passion by the glory of his blood, had both the Lord's righteousness and peace..$^{25}$

Those who have hatred in their hearts, even if they are "slain for the name [of Christ]," 26 will not be crowned as imitators of the righteous Abel (or Christ), but instead be regarded as following in the footsteps of Cain - since "The one who hates his brother is a murderer" 27 and of Judas. ${ }^{28}$ "How great is the sin which cannot even be washed away by a baptism of blood - how heinous the crime which cannot be expiated by martyrdom! ${ }^{29}$

This focus on the heart is also present in De unitate, where Cain provides a warning against having animosity towards others. After citing Mark 11:25 on forgiving before coming to prayer, ${ }^{30}$ Cyprian continues:

And so, if a man comes to the sacrifice with strife in his heart, [Jesus] calls him back from the altar and bids him be reconciled to his brother first,

25 "Neque enim in sacrificiis quae Abel et Cain primi obtulerunt munera eorum Deus, sed corda intuebatur, ut ille placeret in munere qui placebat in corde. Abel pacificus et iustus, dum Deo sacrificat innocenter, docuit et ceteros, quando ad altere munus offerunt, sic uenire cum Deo timore, cum simplici corde, cum lege iustitiae, cum concordiae pace. Merito ille dum in sacrificio Dei talis est, ipse postmodum sacrificium Deo factus est, ut martyrium primus ostendens initiaret sanguinis sui gloria dominicam passionem qui et iustitiam Domini habuerat et pacem." Dom. orat. 24 (CCSL 3A:105).

26 "pro nomine occisus fuerit." Dom. orat. 24 (CCSL 3 A:105).

27 "Quifratrem suum odit homicida est." 1 John 3:15. Dom. orat. 24 (CCSL 3A:105).

28 Dom. orat. 24 (CCSL 3A:105-106).

29 "Quale delictum est quod nec baptismo sanguinis potest ablui, quale crimen est quod martyrio non potest expiari!" Dom. orat. 24 (CCSL 3A:106).

$30 \quad$ Also quoted in Test. 3.22 (CCSL 3:120) and Dom. orat. 23 (CCSL 3A:104-105). 
and then in peace of soul return and make his offering to God. ${ }^{31}$ For neither did God have respect to the gifts of Cain: ${ }^{32}$ such a man could not have God at peace with him when he was torn with jealousy towards his brother and at war with him. ${ }^{33}$

This is one more piece of evidence presented by Cyprian to support his contention that unity is an outward expression of one's inner condition - conflict with one's brethren indicates that one is not in right relationship with God.

Abel's identification as the first martyr also makes him a suitable example for those facing persecution, since he is evidence that the righteous suffer. ${ }^{34}$ So, in writing to the confessors in prison, Cyprian encourages them to look beyond their transitory afflictions and rejoice that they will one day reign with Christ: "You know that it was so ordered from the beginning of the universe that here Righteousness should struggle and wrestle in this world, for at the very beginning the righteous man Abel was slain and thereafter all those righteous men have been slain, both the Prophets and the Apostles whom He sent forth." ${ }^{35}$ Likewise, in $E p .58$, an exhortation to the people of Thibaris who appeared to be facing imminent persecution, a list of those who suffered is headed by Abel:

$31 \quad$ Allusion to Matt 5:23-24. Quoted in Test. 3.3 (CCSL 3:91).

32 Allusion to Gen 4:5 (also in Dom. orat. 24 [CCSL 3A:105]).

33 "et ad sacrificium cum dissensione uenientem reuocat ab altari et iubet prius concordare cum fratre, tunc cum pace redeuntem Deo munus offerre; quia nec ad Cain munera respexit Deus, neque enim habere pacatum Deum poterat qui cum fratre pacem per zeli discordiam non habebat." Unit. 13 (CCSL 3:259). English translation of De unitate from Maurice Bévenot, ed. St. Cyprian: The Lapsed, The Unity of the Catholic Church, New York, 1957.

34 Abel is not mentioned in the section "De bono martyrii," (Test. 3.16 [CCSL 3:107]), neither is he mentioned in the section "Bonos quosque et iustos plus labore sed tolerare debere, quia probantur.” Test. 3.6 (CCSL 3:94). Perhaps because in Ad Quirinum, Cyprian focuses on citing texts without commentary, and Abel is not described as either righteous or a martyr. Abel does appear in Heb 11:4 (Vulgate: "Fide plurimam hostiam Abel, quam Cain, obtulit Deo, per quam testimonium consecutus est esse iustus, testimonium perhibente muneribus eius Deo, per illam defunctus adhus loquitur."). Cyprian never cites that book, however, although Tertullian does. (Pud. 20.1-5 [CCSL 2:1324]). Perhaps Cyprian is picking up on Matt 23:35 which specifically mentions Abel as righteous. Matt 23:35 (Vulgate): "a sanguine Abel iusti usque ad sanguinem Zachariae." The version in Luke 11:51 mentions the prophets (from Abel to Zechariah), but does not specifically use the word "righteous." "scientes ab initio mundi sic institutum ut laboret istic in saeculari conflictatione iustitia, quando in origine statim prima Abel iustus occiditur et exinde iusti quique et prophetae et apostoli missi." Ep. 6.2.1 (CCSL 3 B:32). 
"Let us imitate, dearly beloved brethren, Abel, that just man who inaugurated martyrdom by being the first slain for justice' sake."36

Another similar list on the persecution of the righteous appears in Ad Fortunatum 11, in support of the testimony: "It was predicted beforehand that the world would hate us and stir up persecutions against us, and that nothing new is happening to Christians, since from the beginning of the world the good have suffered, and the righteous have been oppressed and slain by the unrighteous." ${ }^{37}$ After a number of warnings from Jesus, who appears first as the most important exemplar, the ancient evidence for the claim is provided: "Thus, at the very beginning of the world, the righteous Abel was the first to be slain by his brother; and Jacob was driven into exile, and Joseph was sold, and king Saul persecuted the merciful David."38

Likewise, in Ep. 59, Cornelius should not be surprised that he faces opposition from within, since this was predicted in the gospel and even the Lord was betrayed by those closest to him: "So it was, too, in the very beginning of the world. The just Abel was slain by none other than his own brother; Jacob was pursued in flight by his enraged brother; Joseph as a boy was put up for sale with his very own brothers as his traders." 39

Cyprian uses Cain and Abel so frequently because they are prototypes: Abel is the first martyr and type of Christ who suffered for righteousness; Cain is an imitator of the devil, the embodiment of all that goes wrong when one hates his brother. Jealousy and envy are the root of all kinds of evil, including conflict, which the Christian must reject, patiently enduring wrong and maintaining unity and love.

36 "Imitemur, fratres dilectissimi, Abel iustum qui initiauit martyria dum propter iustitiam primus occiditur." Ep. 58.5.1 (CCSL 3 C:325). He then holds up for imitation Abraham (who was prepared to sacrifice his son), the three youths, Daniel, the Maccabean martyrs, the Holy Innocents and Christ. (CCSL 3:325-329).

"Ante praedictum esse quod nos mundus odio habiturus esset et quod persecutiones aduersum nos excitaret et quod nihil nouum christianis accidat, quando ab initio mundi boni laborauerint et oppressi adque occisi sint iusti ab iniustis." Fort. 11 (CCSL 3:201).

38 "Sic in origine statim mundi Abel iustus a fratre primus occiditur et Iacob fugatur et Ioseph uenundatur et Dauid misericordem Saul rex persequitur." Fort. 11 (CCSL 3:204). Followed by Elijah at the hands of Ahab, Zechariah, the three youths, Daniel, Tobit, the seven Maccabean brothers and Eleazar. The crowd of martyrs in Revelation, which cannot be numbered, is used in contrast to these ancient examples, which can be. Fort. 11 (CCSL 3:204-211). "inter initia quoque mundi Abel iustum non nisi frater occiderit et Iacob fugientem persecutus sit frater infestus et Ioseph puer uenierit uendentibus fratribus." Ep. 59.2.4 (CCsL 3C:339). 
The next in line in Cyprian's discussion of jealousy and envy is the pairing of Esau and Jacob: "And that Esau was hostile to his brother Jacob, arose from jealousy also. For because the latter had received his father's blessing, the former was inflamed to a persecuting hatred by the brands of jealousy." 40 These two also appear on De bono patientiae, Jacob first as an example of patience: "And Jacob, driven forth by his brother from his country, departs with patience; and afterwards, with greater patience, he suppliantly brings him back to concord with peaceful gifts, when he is even more impious and persecuting." ${ }^{11} \mathrm{Ja}$ cob certainly suffered at the hands of Esau, but Cyprian never mentions the deception which enabled Jacob to procure Isaac's blessing. Later in De bono patientiae, Esau is listed among the impatient over a separate incident: "And in that Esau descended from the rights of the first-born to those of the younger, he lost his priority by impatience for the pottage." 42

Cyprian also uses Jacob and Esau to make several other points. Esau's foolish selling of his birthright provides a warning against conceding baptism to the heretics: "And the Holy Scriptures make plain to us what peril there is in affairs of God if you surrender your rights and power: in Genesis Esau lost in that way his birthright and was unable later to recover what he had once surrendered."43 Jacob, on the other hand, plays a typological role in Ad Quirinum..$^{44}$ In support of the testimony, "That the Church which before had been barren would have more children from among the Gentiles than what the synagogue had before," 45 Jacob's two wives represent the synagogue (Leah) and the church (Rachel). ${ }^{46}$

40 "Et quod Esau fratri suo Iacob inimicus extitit zelus fuit: nam quia ille benedictionem patris acceperat, hic in odium persecutionis facibus liuoris exarsit." Zel. liv. 5 (CCSL 3A:77).

"et Iacob fugatus a fratre de terra sua patienter excedit et maiore patientia postmodum supplex adhuc magis impium et persecutorem muneribus pacificis ad concordiam redigit." Pat. 10 (CCSL 3A:123). As mentioned above, Jacob is also used as an example in Ad Fortunatum: "Iacob fugatur," Fort. 11 (CCSL 3:204), and as a precedent for being persecuted by one's brother in Ep. 59.2.4 (CCSL 3C:339).

"et quod Esau de maioribus ad minora descendit, primatus suos per impatientiam lentis amisit." Pat. 19 (CCSL 3A:129).

"Quam periculosum sit autem in diuinis rebus ut quis cedat iure suo et potestate scriptura sancta declarat, cum in Genesi Esau primatus suos inde perdiderit nec recipere id postmodum potuerit quod semel cessit." Ep. 73.25.1 (CCSL 3 C:56o).

44 For a defence of Ad Quirinum as Cyprian's work, see Edwina Murphy, "'As Far as My Poor Memory Suggested': Cyprian's Compilation of Ad Quirinum," vc, 68 (2014), pp. 533-550. "Quod ecclesia quae prius sterilis fuerit plures filios habitura esset ex gentibus, quam quod synagoga ante habuisset." Test. 1.20 (CCSL 3:19).

46 Test. 1.20 (CCSL 3:20). Cyprian does not follow Tertullian in identifying Jacob and Esau as representatives of Jews and Christians. On Tertullian's use of Rebekah's twins, see 
For the testimony, "That [Christ] also is called a Stone,"47 the stone Jacob placed at his head as he slept ${ }^{48}$ represents Christ, since the head of man is Christ. ${ }^{49}$ While Jacob and Esau can be useful in these other contexts, paired together they primarily serve as further confirmation of the divisive nature of jealousy and the longsuffering patience of the Lord's anointed.

\section{$4 \quad$ Joseph and his Brothers}

Unsurprisingly, the next to appear in De zelo et livore as examples of envy are Joseph's brothers: "And that Joseph was sold by his brethren,,0 the reason of their selling him proceeded from envy. When in simplicity, and as a brother to brethren, he set forth to them the prosperity which had been shown to him in visions, their malevolent disposition broke forth into envy."51 Joseph is presented as innocent: he simply shares with his brothers what he has seen, but their jealousy of his future glory leads them to rise up against him. No specific mention is made of how he responded to their envy here, but that comes out in De bono patientiae: "Joseph, sold by his brethren and exiled, not only patiently forgives them, but even freely, generously and mercifully bestows corn when they come to him."52 Unlike Cain and Esau, Joseph's brothers are not mentioned in Pat. 19 - Cyprian does not attribute their wrongdoing to impatience.

Joseph is described as a type of Christ in Ad Quirinum, ${ }^{53}$ but his experience is also a precursor to Cyprian's own in receiving opposition to his dreams. Here his opponents are cast in the role of Joseph's brothers:

I am very well aware that dreams and visions are thought by some people to be silly and absurd, but it is precisely those very people who instead of

Geoffrey D. Dunn, “Tertullian and Rebekah: A Re-Reading of an 'Anti-Jewish' Argument in Early Christian Literature," vc, $5^{2}$ (1998):120-122.

"Quod idem et lapis dictus sit." Test. 2.16 (CCSL 3:51). This testimony is one of the few in Ad Quirinum where Cyprian does not simply cite the verses.

48 Gen 28:10-18.

49 Alluding to 1 Cor 11:3. Test. 2.16 (CCSL 3:52).

$50 \quad$ Also, as mentioned above, appearing in Fort. 11 (CCSL 3:204): "Ioseph uenundatur."

51 "Et quod Ioseph fratres sui uendiderunt, causa uendendi de aemulatione descendit: postquam id quod sibi in uisionibus prosperum fuerat ostensum simpliciter ut fratribus frater exposuit, in inuidiam maliuolus animus erupit." Zel. liv. 5 (CCsL 3A:77).

"Ioseph uenumdatus a fratribus et relegatus non tantum patienter ignoscit, sed et gratuita uenientibus frumenta largiter et clementer impertit." Pat. 10 (CCSL 3A:123-124). 
believing in their bishops would rather believe anything against them. Yet it does not surprise me, when even Joseph's own brothers said of him: "Look, here comes that dreamer. Come now, let us kill him." But the dreamer afterwards saw accomplished what he had dreamed, to the confusion of those who would sell and slay him: though they refused to believe his words, they were later forced to believe them now verified as deeds. ${ }^{54}$

Cyprian looks to his future justification, just as Joseph was ultimately vindicated. Those who belittle him now may well have to humble themselves later.

In De zelo et livore, the relationship between Saul and David is developed in the light of Saul's jealousy over David's accomplishments, even when the victory was due to God's intervention:

Furthermore, that Saul the king hated David, seeking by oft-repeated persecutions to kill him - innocent, merciful, gentle, patient in meekness what else was the provocation except the spur of jealousy? Because, when Goliath was slain and by the aid and condescension of God so great an enemy was defeated, and the wondering people burst out in acclamation in praise of David, Saul through envy conceived the fury of hostility and persecution. ${ }^{55}$

Whilst Saul is depicted as consumed by jealousy, David's many virtues are reinforced in De bono patientiae, with particular emphasis on his role as a forerunner of Christ. ${ }^{56}$ His patience is therefore identified as Christian:

54 "Quamquam sciam somnia ridicula et uisiones ineptas quibusdam uideri, sed utique illis qui malunt contra sacerdotes credere quam sacerdoti. Sed nihil mirum, quando de Ioseph fratres sui dixerunt: 'ecce somniator ille uenit, nunc ergo uenite, occidamus illum,' et somniator postea quod somniauerat consecutus sit et occisores ac uenditores confusi sint, ut qui uerbis prius non credidissent factis postmodum crederent." Ep. 66.10.2 (CCSL 3C:444-445).

"Saul quoque rex ut Dauid odisset, ut persecutionibus saepe repetitis innocentem, misericordem, miti lenitate patientem necare cuperet, quid aliud quam zeli stimulus prouocauit? Quia Goliath interfecto et ope ac dignatione diuina tanto hoste deleto populus admirans in laudes Dauid praedicationis suffragio prosiliit, Saul simultatis adque insectationis furias de liuore concepit." Zel. liv. 5 (cCSL 3A:77).

$5^{6}$ In Test. 2.11, a series of texts are quoted to demonstrate "That he was to be born of the seed 
Moreover, in David, from whom, according to the flesh, the birth of Christ arises, how great and marvellous and Christian is the patience, that he often had it in his power to be able to kill king Saul, who was persecuting him and desiring to slay him; and yet, [David] chose instead to save him when he was placed in his hand and handed over to him, not repaying his enemy in turn, but rather, on the contrary, even avenging him when he was killed!57

Not only did David restrain himself from retaliating against Saul, says Cyprian, but his patience extended even to treating him as his own kin. In addition, as mentioned above, one of the evidences presented for the claim that the righteous will suffer is that "king Saul persecuted the merciful David." ${ }^{58}$ Here David's mercy is emphasised once more, perhaps because Cyprian particularly identifies him with Christ. In Ad Quirinum, on the other hand, instead of David himself being a type of Christ, Christ is the stone with which David kills Goliath, who symbolises the devil. ${ }^{59}$ Cyprian, like the author of Chronicles, overlooks David's failures and only presents him in a positive light.

Saul, however, is a negative figure. In a letter to Rogatianus and his companions, ${ }^{60}$ he is mentioned, in company with Solomon, as a warning against failing to persevere. Cyprian quotes and rewrites John 5:14:

This is a lesson which the Lord has taught us on His own authority with these words: Look, you have been made whole. Sin no more lest something worse befall you. Imagine the Lord now saying this also to His confessor: "Look, you have been made a confessor. Sin no more lest something worse befall you." ${ }^{\text {61 }}$ When Solomon and Saul and many others ceased to walk in

of David according to the flesh." "Quod de semine Dauid secundum carnem nasci haberet." Test. 2.11 (CCSL 3:43-44).

"In Dauid uero, ex quo secundum carnem Christi natiuitas oritur, quam magna et mira et christiana patientia habuisse in manu saepe ut Saul regem persequentem se et interficere concupiscentem posset occidere et tamen subditum sibi et traditum maluisse seruare nec rependisse inimico uicem, sed occisum adhuc insuper et uindicasse!" Pat. 10 (CCSL 3A:124).

$5^{8} \quad$ "Dauid misericordem Saul rex persequitur." Fort. 11 (CCSL 3:204).

59 "Hic est lapis item in Basilion primo, quo Dauid frontem Goliae percussit et occidit, signifcans diabolum et seruos eius inde prosterni uictos scilicet ea capitis parte, quam signatam non habent: quo signo nos et tuti sumus semper et uiuimus." Test. 2.16 (CCSL 3:52-53). In support of the testimony, "Quod idem et lapis dictus sit." Test. 2.16 (CCSL 3:51).

$60 \quad$ Dated before mid-April, 250 by Clarke, Letters, vol. 1, p. 254.

$61 \quad$ The rewriting of Scripture here is, as Clarke says, "intended to be arrestingly emphatic." Clarke, Letters, vol. 1, p. 256 n. 5. Cyprian rarely uses this strategy; when he does, he quotes 
the pathways of the Lord, they were unable to keep the grace that had been given to them; as they abandoned the teachings of the Lord, so His grace abandoned them. ${ }^{62}$

Here there is the implication that Solomon and Saul at least started well. ${ }^{63}$ However, Saul does not appear even to have done that in a letter to the Bishop Rogatianus who has suffered insubordination at the hands of his deacon. ${ }^{64}$ Cyprian points out that Samuel was scorned because of his age, just as Rogatianus was, but God avenged him: "He raised up Saul to be their King to beset them with grave hardships and to tread underfoot and oppress this arrogant nation with all kinds of insult and punishment."65

Whereas David embodies the patience and mercy of Christ, loving his enemies, Saul rejects God's means of deliverance and instead succumbs to the malevolent impulses of jealousy.

The final illustration of the danger of envy is provided by the Jews. In the previous examples, the negative effects of jealousy were mostly borne by the

the original verse before adapting it. See 1 Tim 4:12 in Ep. 3.3.3 (CCsL 3 B:15) and Matt 25:36 in $E p$. 62.3.1 (CCSL $3 \mathrm{C}: 387$ ).

62 "Dominus hoc magisterio suo docuit dicens: 'ecce sanus factus es, iam noli peccare, ne quid tibi deterius fiat.' Puta hoc illum et confessori suo dicere: 'ecce confessor factus es, iam noli peccare, ne quid tibi deterius fiat.' Salomon denique et Saul et ceteri multi quamdiu in uiis domini ambulauerunt, datam sibi gratiam tenere potuerunt: recedente ab his disciplina dominica recessit et gratia." Ep. 13.2.2 (CCSL 3 B:72-73). As Hübner says, if discipline is of the greatest importance for salvation, then the reverse is also true: the undisciplined lose grace and perish. Siegfried Hübner, "Kirchenbuße und Exkommunikation bei Cyprian," ZKT, 84 (1962), p. 6 o.

63 Solomon is used in a similar context in De unitate as a warning to confessors to continue in the ways of the Lord, (Unit. 20 [CCSL 3:264]), having been referred to earlier in the work with regard to the division of the kingdom. Unit. 7 (CCSL 3:254). He is also identified as withdrawing from the ways of the Lord, followed by a quote from 1Kgs 11:14a, in Dom. orat. 25 (CCSL 3 A:106). Earlier in his life, the Holy Spirit had spoken through him, referring to Prov 9:1-5. Ep. 63.5.1-2 (CCSL 3C:394-395).

64 The letter likely belongs in the period $25^{2-255}$. It is uncertain whether this is the same Rogatianus mentioned in Ep. 3, now elevated to the episcopate, or a different one - the name is fairly common in Africa. For discussion, see Clarke, Letters, vol. 1. p. 164-165.

65 "excitauit eis Saul regem, qui eos iniuriis grauibus adfligeret et per omnes contumelias et poenas superbum populum calcaret et premeret." Ep. 3.1.2 (CCSL 3B:11). 
innocent parties, but here, just as occurred with the devil himself, envy results in the downfall of those who embrace it:

And, not to go to the length of numbering each one, let us observe the destruction of a people that perished at once. Did not the Jews perish for this reason, that they chose rather to envy Christ ${ }^{66}$ than to believe Him? Disparaging those great works which he did, they were deceived by blinding jealousy, and could not open the eyes of their heart to the knowledge of divine things. ${ }^{67}$

Cyprian's reference to the Jews here suggests that he relegates them to the past rather than considering them to be a present threat to the church. ${ }^{68}$

The Jews are also present in De bono patientiae, but here it is Moses who first shows patience in his dealings with them: "Moses is frequently held in contempt by an ungrateful and faithless people, and almost stoned; and yet he gently and patiently entreats the Lord for those same people." 69 In chapter 19, the Jews again appear, beginning with their impatience when Moses was on the mountain, but extending to an impatience with God's commands which led to putting to death the righteous and, ultimately, Christ:

Why were the Jewish people unfaithful and ungrateful regarding the divine benefits? Was it not the crime of impatience, that they first departed from God? They could not bear the delay while Moses was talking with God, they dared to demand pagan gods, in order that that the leaders of their journey might be the head of an ox and an earthen image; nor did they ever hold back from their impatience, until, always impatient of being compliant and of divine admonition, they put to death

66 Matt 26:18.

67 "Et ne longum faciam singulos recensendo, pereuntis semel populi adtendamus interitum. Iudaei nonne inde perierunt, dum Christo malunt inuidere quam credere? Obtrectantes magnalibus quae ille faciebat zelo excaecante decepti sunt nec ad diuina noscenda cordis oculos aperire potuerunt." Zel. liv. 5 (CCSL 3A:77). Note allusion to Eph 1:18.

68 For discussion of this point, see Charles Arnold Bobertz, "For the Vineyard of the Lord of Hosts was the House of Israël': Cyprian of Carthage and the Jews," JQR, 82 (1991), pp. 1-15. Bobertz does not cite this passage, however, as his focus is on Cyprian's use of verses from Book 1 of Ad Quirinum (which displays a supercessionist stance) elsewhere in his work.

69 "Moyses ab ingrato et perfido populo contemnitur frequenter et paene lapidatur, et tamen lenis et patiens pro eisdem Dominum deprecatur." Pat. 10 (CCSL 3A:124). 
their prophets and all the righteous men, and plunged even into the crime of the crucifixion and blood shedding of the Lord. ${ }^{70}$

The Jewish people as a whole are used to label and condemn opponents, even though all the righteous people listed were, of course, Jews. And so heretics are inflicted with this same impatience, being imitators of the Jews rather than of Christ, the source of peace and charity. In short, "absolutely everything which patience, by its works, builds up to glory, impatience casts down into ruin."71

For Cyprian, jealousy "is the root of all evils ... by this the bond of the Lord's peace is broken, by this brotherly charity is violated, by this truth is adulterated, unity divided, people plunge into heresies and schisms."72 Paul Blowers sees this reference as an indication that Cyprian "is addressing the bitter schisms and clerical jockeying in the churches of North Africa and Rome over the reconciliation of the lapsed." ${ }^{3}$ This is certainly the case, but Cyprian's concern runs deeper. As Odd Magne Bakke says, while unity is expressed in the structure of the church, for Cyprian, it is through love and patience that such unity is maintained. ${ }^{74}$ These are the hallmarks of those who imitate Christ. Likewise, dissension and rivalry bear the imprint of the devil.

The supernatural battle between good and evil is replicated in the lives of biblical exemplars. In De zelo et livore, Cyprian emphasises the origins of jealousy, particularly its progenitor, the devil, and the beginnings of human history, with Cain and Abel playing a paradigmatic role. The use of similar characters

$70 \quad$ "Quid Iudaicus populus circa beneficia diuina perfidus et ingratus? Nonne quod a Deo primum recessit impatientiae crimen fuit? Dum Moysi cum Deo colloquentis moras non potest ferre, profanos deos ausus est postulare, ut itineris sui duces nuncuparet caput bubulum et terrestre figmentum, nec umquam ab eadem impatientia destitit quominus semper docilitatis et diuinae administrationis impatiens prophetas suos et iustos quosque perimendo ad crucem quoque et sanguinem Domini prosiliret." Pat. 19 (CCSL 3A:129).

71 "omnia omnino quae patientia operibus suis aedificat ad gloriam impatientia destruit ad ruinam." Pat. 19 (CCSL 3A:129).

72 "Radix est malorum omnium. ... Hinc dominicae pacis uinculum rumpitur, hinc caritas fraterna uiolatur, hinc adulteratur ueritas, unitas scinditur, ad haereses adque ad schismata prosilitur..." Zel. liv. 6 (ccsL 3A:78).

73 Paul M. Blowers, "Envy's Narrative Scripts: Cyprian, Basil, and the Monastic Sages on the Anatomy and Cure of the Invidious Emotions," MT, 25 (2009), p. 27.

74 Odd Magne Bakke, "The Episcopal Ministry and the Unity of the Church from the Apostolic Fathers to Cyprian," in The Formation of the Early Church, ed. Jostein Ådna, Tübingen, 2005, p. 406. 
in De bono patientiae indicates that, for Cyprian, jealousy and envy are the opposite of patience since they are opposed to love, which requires patience to be preserved. But these models are not confined to the pages of scripture they are to be emulated (or repudiated) in the life of the Christian. As Cyprian directs, "Love those you previously hated; esteem those you envied and unjustly disparaged. Imitate the good, if you can follow them; if you cannot follow them, at least rejoice with them, and congratulate those who are better than you. 75

Furthermore, the many similarities between De bono patientiae and De zelo et livore indicate that they are indeed companion pieces, ${ }^{76}$ despite Hugo Koch associating the latter work with De unitate. ${ }^{77}$ Since Tertullian identifies the devil as the originator of jealousy in De patientia, and Cyprian uses that work as a basis for De bono patientiae, using many of the same examples, ${ }^{78}$ it is likely that it was written first. In De zelo et livore, then, Cyprian takes those same examples to address the issue of jealousy and envy, using the text from Wisdom as a framing device. While both works are concerned with unity, De bono patientiae has a particular focus on waiting for God's vengeance rather than retaliating. On the other hand, De zelo et livore warns against the wiles of the devil and the personal turmoil which results from harbouring jealousy.

Cyprian's use of these models demonstrates the importance of this reading strategy for his exegesis and the value he ascribes to imitation in Christian formation. This study also highlights that Cyprian's well-known emphasis on unity is not simply a matter of avoiding schism. Rather, structural concerns are just one expression of Cyprian's conviction that conflict and division are vices rooted in the flesh. Rather than imitating the devil in jealousy and envy, those who claim to be Christians must, like Christ, live according to the Spirit in love and peace.

75 "Ama eos quos ante oderas, dilige illos quibus iniustis obtrectationibus inuidebas. Bonos imitare, si sectari potes; si sectari non potes, conlaetare certe et gratulare melioribus." Zel. liv. 17 (CCSL $3 A: 85)$. The sentiment echoes that of Sallust regarding the Roman attitude to the achievements of other cultures: "they preferred to emulate their merits rather than envy them" (imitari quam invidere bonis malebant). Sallust, Bellum Catilinae 51 (LCL 116:116-117). As suggested by their placement next to each other in Pontius' list, although it does not necessarily give the works in chronological order. Vit. Cypr. 7 (CSEL 3.1:xcvii-xcviii).

Hugo Koch, Cyprianische Untersuchungen, Bonn, 1926, pp. 132-136. The theme of unity extends throughout Cyprian's episcopate, at least from 251, which is why Poirier says that there is nothing in the content of De zelo et livore to restrict it to a particular period. Poirier, Jalousie et l'envie, p. 9. De bono patientiae can be confidently dated to 256 , as it is referred to in Ep. 73.26.2 (CCSL 3C:562). Clarke, Letters, vol. 4, p. 219.

78 As Sage says, however, these "elements from Tertullian ... are changed and arranged in an entirely new manner.” Michael M. Sage, Cyprian, Philadelphia, PA, 1975, p. 374. 